28) T. Okuyama, T. Fueno, J. Furukawa: Bull. Chem. Soc. Japan, 43, 3256 (1970)

29) C. G. Overberger, D. Tanner, E. M. Pearce: J. Am. Chem. Soc., 80, 4566 (1958)

30) D. S. Noyce, H. S. Avarbock: J. Am. Chem. Soc., 84, 1644 (1962)

31) J. E. Dubois, A. Schwarcz: Tetrahedron Lett., 2167 (1964)

32) H. P. Rothbaum, I. Ting, P. W. Robertson: J. Chem. Soc., 980 (1948)

33) D. S. Noyce, D. R. Hatter, F. B. Miles: J. Am. Chem. Soc., 90, 4633 (1968)
34) W. L. Orr, N. Kharasch: J. Am. Chem. Soc., 78, 1201 (1956)

35) K. Yates, W. V. Wright: Can. J. Chem., 45, 167 (1967)

36) T. Okuyama, T. Fueno: J. Polymer Sci., A-1, 9, 629 (1971)

37) T. Okuyama, T. Fueno, J. Furukawa: J. Polymer Sci., 7, 2433 (1969)

38) T. Higashimura, T. Masuda, S. Okamura, T. Yonezawa: J. Polymer Sci., 7, 3129 (1969)

39) 奥山 格, 椚座清光, 笛野高之 : 第 19 回高分 子年次大会発表, 1970年 5 月, 東京

\title{
PVA と水および脂肪族低級アルコール類との活性水素交換反応
}

\author{
（1970年 8 月 3 日受理）
}

\section{高橋直通*・鈴木文男*・小野里健二*}

\begin{abstract}
要 旨 PVA 結晶内での重水素交換反応機構を検討するために, PVA 水溶液からっくった乾煤 皮膜（結晶化度 $29 \%$ ）と，これを熱処理したるの（結晶化度 $50 \%$ ）について，いろいろな实験条件 下で水および低級脂肪族アルコール類との活性水素の交換反応を行ない, 反応率を IR スペクトル 法で測定した。水との交換反応に扔いては最終的には $100 \%$ の反応率を示し，結晶内も简単に反応 することがわかった。膜厚および反応温度と反応速度との関倸から水の皮膜内への吸着拉よびそれ に伴う非晶領域の可塑化が反応機構に関保していることを示した。PVAと親和性が少なく，結晶 領城に拡散侵人することのむずかしいアルコール類との交換反応も，水の場合と同様に $100 \%$ の反 応率を示すことから，結晶領域内においてはプロトン移動のような機粠で反応が進むものと推測し た。また反応速度が(1)膜厚に反比例すること，(2)結晶化度に無関係であること，(3)エタノールおよ びnープロパノールなどの蒸気圧に比例することなどから, 非晶領域内においてもプロトン移動が交 換反応機構に關倸しているものと推測された。この機構は水との反応の場合も部分的に適用される ものと考えられた。
\end{abstract}

\section{1. 緒言}

さきに著者ら ${ }^{1)}$ はPVA 纎維と重水との活性水素の交 換反応を検討し，繊維の熱処理の有無にかかわらず重水 の PVA 纎維 (OH 基) に対する Accessibility は終局的 には $100 \%$ を示すことを報告した。この事実はPVAの 結晶領域中の $\mathrm{OH}$ 基も非晶領域と同じように完全に重水 素化されることを示している。仁田, 関, 田所ら2) は以 前にPVA 皮膜の重水蒸気による重水素化を赤外線吸収 スペクトルによって検討し，結晶化度に差があるにもか かわらず OH 基の 90 95\% が重水素化されたことを報 告しており，交換反応にプロトン移動の機構を提案して

* 山形大学工学部高分子化学科 (山形県米沢市城南43-16)
いるが，現在までのところこの考えに対して理論的にも 実験的にも賛否を示寸報告がない。

最近石川, 宮坂, 山本ら ${ }^{8)}$ はX線回折によって, 水蒸 気の収着のために PVA 結晶の格子定数が变化すること を認めており，この結果によると重水が PVA 結晶格子 の中に拡散し, その位置の $\mathrm{OH}$ 基を重水素化する機構も 考えられる。

この点を明らかにするために, 著者らは PVA 結晶領 域の中に拢散侵入しにくいと考えられる脂肪族低級アル コールと PVA との活性水素の交換反応を検討した。む し重水素化アルコール (R-OD) が非晶領域にのみ拡散 しその位置の $\mathrm{OH}$ 基を重水素化するならば, 平衡時の重 水素化度はアルコールの拡散䉈囲に見合う非晶量を示す はずである。またもし両領城のすべての OH 基が反応 
するならば, プロトン移動が少なくとも結晶領域の重水 素化機構として考えられ, PVA と重水との活性水素交 換反応機構の一つとして重要な意味をもつことになる。

よって著者らは PVA 皮膜を試料として，まず重水に よる重水素化反応を調べ，さらにモノ重メタノール，エ タノールおよびnープロパノールによる水素交換反応を 検郡した。

\section{2. 試料および実験法}

\section{1 試料の作憋}

PVA は琍クラレ製“ポバール”117 を用い，その残 存酶酸基のモル数にして約 3 倍量の水酸化ナトリウムを 含むアルカリ溶液で再ケン化し，それをセロハンチュー ブによる流水透析および電解透析によって精製し，適当

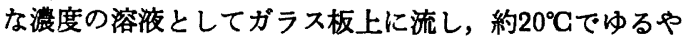
かに水分を蒸発させて皮膜をつくった。これを“無処理 皮膜”とよぶ。図にはNT の記号で表わす。

その一部は窒素気流中で $180^{\circ} \mathrm{C}$ に10分間熱処理を行な った。この試料を“熱処理皮膜”とよび，図には HT と 示す。

これらの試料は交換反応に際しては $70^{\circ} \mathrm{C} て ゙ 48$ 時間真空 乾燥を行なったが，これらの乾燥皮膜をベンゼン一四塩 化炭素を媒体とする密度勾配管によって密度を測定した ところ, 無処理皮膜は $1.29 \mathrm{~g} / \mathrm{cm}^{3}$, 熱処理皮膜は $1.36 \mathrm{~g}$ $/ \mathrm{cm}^{\mathrm{s}}$ であった。これから密度法による結晶化度を計算 するとそれぞれ $29 \%$ およ゙ $50 \%$ に相当する。なお赫外線 吸収スペクトルの結晶化バンドに基ついて求めた結晶化 度はそれぞれ31\%および51\%であった。

反応に用いた重水は昭和電工琍製の Deuterium 濃度 99.8\%のもので，真空蒸留によって精製した。

モノ重メタノールは Merk 社製スペクトル用のものを そのまま使用した。

重水素化反応に用いたエタノールおよび $n$-プロパ， 一ルは酸化カルシウムおよび水素化カルシウムで完全に 脱水してから，液体空素を冷媒とする真空蒸留によって 精製した。

メタノールは水素化カルシウムで脱水するとアンモニ アの生成が認められたので, Evars らい)の方法に従って 金属マグネシウム，硝酸銀および活性アルミナを用いて 脱水し, 真空蒸留して精製した。

\section{2 交換反応およひ重水素化度の測定法}

PVA の重水素化は岡島, 甲斐ららの方法に準じて行な った。その装置を Fig. 1 に示す。PVA 皮膜 (a) は黄銅リ ング(c) を用いてガラスセル (b) の中にはった。セルの空 に用いたガラス板 (d) は約 $0.4 \mathrm{~mm}$ の厚さの顕微鏡用ス ライドガラスで, 赤外線吸収性の少ないものを選んでエ ポキシ椡脂によってセルの両側にはりつけて空とした。 测定にあたっては反応セルと同蜇のガラス板をはった補

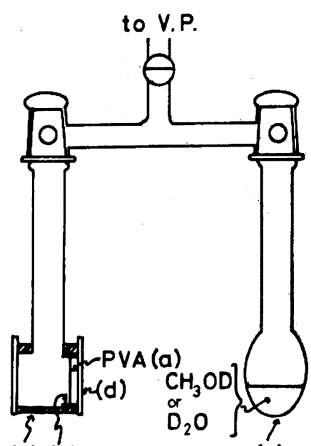

(b) (c)

(e)

(a): PVA membrane, (b): Reaction cell, (c): Brass ring, (d): Glass window, (e): Reservoir

Fig. 1. Reaction apparatus.

償セルを補償光路に入れ，重水素化度を測定する波長範 囲に妨害となるような吸収の発生を防いだ。

PVA 皮膜をはったセルは真空ラインに取付け，70 で48時間真空乾燥したのち，乾燥空気を入れて常圧にも どし，真空ラインからはずして島津 IR-27G 赤外線吸収 スペクトル装置にかけ基準吸光度を求めた。セルをふた たび真空ラインにもどし，排気してから重水あるいは重 メタノール蒸気を容器 (e) からセルに導入し, 所定の温度

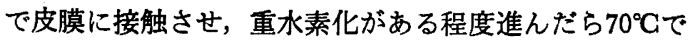
1 時間真空乾燥し, 前と同様にして赤外線吸収スペクト ルの測定を行なった。この操作を重水素化が平衡に達す るまでくり返した。

水素交換反応率の測定には赤外線吸収スペクトルの $3340 \mathrm{~cm}^{-1}$ のレ $(\mathrm{OH})$ 吸収バンドに対してベースライン 法を適用したが，その際 $2910 \mathrm{~cm}^{-1}$ のレ(CH) バンドを 定量の基準として用いた。 $3340 \mathrm{~cm}^{-1}$ バンドの吸光度と 皮膜の厚さとの間には直線関係が得られたので，このス ペクトロスコピーに対して Beer の法則がなりたつと考 えられる。よって交換反応率は次式によって求めた。

$$
\text { 水素交換反応率 }=1-\frac{D^{a} \mathrm{OH}}{D^{p} \mathrm{OH}}
$$

ただし $D^{p} \mathrm{OH}$ ：反応前の補正された $3340 \mathrm{~cm}^{-1}$ の吸光 度

$D^{a}{ }_{\mathrm{OH}}$ ：反応後の補正された $3340 \mathrm{~cm}^{-1}$ の吸光 度 とする。

\section{3. 実験結果および考察}

\section{1 重水蒸気による重水素化}

\section{1 .1 皮膜の厚さの影罯}

PVA の OH 基の水素のアルコール類による交換反応 に先だち，基本となる重水蒸気との反応を行ない，反応 


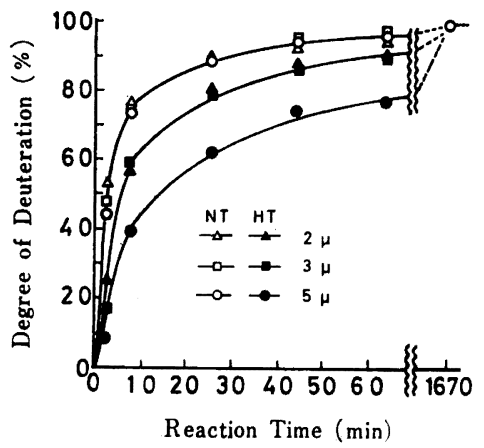

Reaction temperature: $25^{\circ} \mathrm{C}$

Vapor pressure of $\mathrm{D}_{2} \mathrm{O}: 21 \mathrm{mmHg}$

$\mathrm{HT}$ : PVA membrane heat treated at $180^{\circ} \mathrm{G}$ in $\mathrm{N}_{2}$ atmosphere

NT: none treated PVA membrane

Fig. 2. Deuteration rates of PVA membranes with $\mathrm{D}_{2} \mathrm{O}$ vapor. Influence of thickness and heat treatment of membrane.

温度 $25^{\circ} \mathrm{C}$, 相対湿度 $90 \%$ の条件下で実験した。無処理皮 膜および熱処理皮膜の二種の試料について皮膜の厚さが それぞれ 2,3 および $5 \mu$ のものを用いたが，これらの試 料は同一PVA 溶液を 3 分してまったく同一条件下で蔽 膜したものであり，厚さが異なる以外はほぼ同じ性状の ものである。

重水素化反応速度曲線を Fig. 2 に示す。これによれば 反応初期には重水素化がすみやかに進み, 約10分後には 両試料とも非晶部分の $\mathrm{OH}$ 基がほとんどすべて重水素 化されたと考えられる反応率に達した。この付近から反 応速度は著しく低下したが，1670分後にはすべての OH 基は完全に重水素化されていた。

反応のきわめて初期には厚みの違いによる重水素化度 の差が観察され, Table 1 に示すように反応率は膜厚に 反比例することが認められた。

しかし反応が進み非晶領域の重水素化がほぼ完了した とみられる時点からは反応率に厚さの影響はみられなく

Table 1. Relation between membrane thickness and initial degree of deuteration with $\mathrm{D}_{2} \mathrm{O}$ vapor. a)

\begin{tabular}{c|c|c}
\hline $\begin{array}{c}\text { Membrane thickness } \\
(l) \times 10^{8} \mathrm{~mm}\end{array}$ & $\begin{array}{c}\text { Degree of deute- } \\
\text { ration }(D)\end{array}$ & $\begin{array}{c}(l) \times(D) \times 10^{8} \\
(\mathrm{~mm})\end{array}$ \\
\hline 2.0 & 0.258 & 0.52 \\
3.0 & 0.177 & 0.52 \\
5.0 & 0.105 & 0.53 \\
\hline
\end{tabular}

a) Reaction time: 2 minutes,

Reaction temperature: $25^{\circ} \mathrm{C}$,

Sample: Heat treated membrane,

Vapor pressure of $\mathrm{D}_{2} \mathrm{O}: 21 \mathrm{mmHg}$
なり，結晶化度の違いによる反応速度の差のみが認めら れた。

これは初期においては非晶領域に対する水分子の拡散 が律速段階であり，膜厚の影響が現われるものと考えら れる。しかし水分子が収着され，その膨潤可塑化効果に よって非晶領域内での水分子の移動がすみやかになる と，反応率に対する膜厚の影響は消え，結晶領域との反 応が律速段階となるために結晶化度のみが影響するよう になると考えられる。

\section{1 .2 反応温度の影軋}

次に反応温度の影響を調べた。いずれも厚さ $3 \mu$ の無

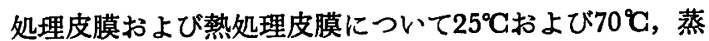
気圧 $18 \mathrm{mmHg}$ のもとで行なった実験結果を Fig. 3 に示

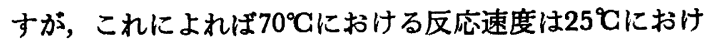
るものに比べて明らかに小さい。

この現象を確認するために次の実験を行なった。すな

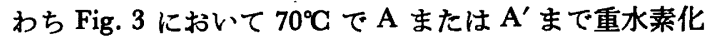
したものを $25^{\circ} \mathrm{C} て ゙$ 常水の蒸気と 10 分間接触させて再水素 化すると重水素化度は B または $\mathrm{B}^{\prime}$ まで低下した。引続 き $70^{\circ} \mathrm{C}$ で 10 分間重水蒸気に接触させて再重水素化した が，試料の重水素化度は $\mathrm{C}$ または $\mathrm{C}^{\prime}$ までしか回復しな かった。すなわち気相での水素交換反応では反応温度の 高いほらが反応速度が遅いことが明らかになった。

これについては次の上うに考えられる。すなわち，25 'Cにおける重水素化反応の場合は反応セル内の相対湿度 は90\%であるが，同じ圧力の下で $70^{\circ} \mathrm{C}$ の場合は約 $8 \%$ 以 下に低下する。したがって皮膜に収着される重水の量に 大きな相違が起こっているはずである。事実著者らの測

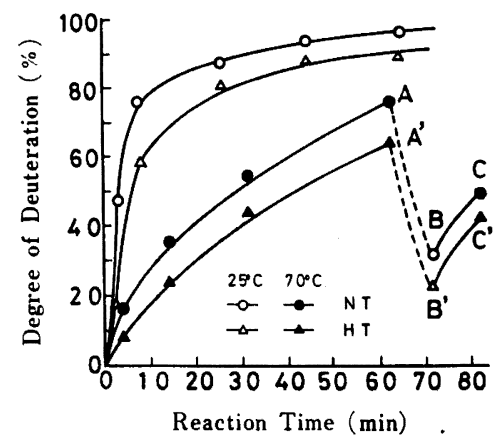

Membrane thickness: $3 \mu$

Vapor pressure of $\mathrm{D}_{2} \mathrm{O}$ and $\mathrm{H}_{2} \mathrm{O}: 21 \mathrm{mmHg}$

A, $A^{\prime}-\cdots-B, B^{\prime}$ : Rehydrogenation at $25^{\circ} \mathrm{C}$

$\mathrm{B}, \mathrm{B}^{\prime}-\mathrm{C}, \mathrm{C}^{\prime}$ : Redeuteration at $70^{\circ} \mathrm{C}$

$\mathrm{HT}$ : PVA membrane heat treated at $180^{\circ} \mathrm{C}$ in $\mathrm{N}_{2}$ atmosphere

NT: None treated membrane

Fig. 3. Deuteration rates of PVA membranes with $\mathrm{D}_{2} \mathrm{O}$ vapor. Influence of reaction temperature. 


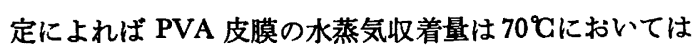
$25^{\circ} \mathrm{C}$ における場合の約 $1 / 20$ にすぎなかった。この点から 考えて PVA 皮膜の非晶領域の膨潤が 重水分子の拡散を はやめ, 反応速度を大きくしていると思われる。この点 は後に述べるアルコール類との反応機構と大いに異なる ところである。

\section{2 モノ重メタノールによる重水素化}

\subsection{1 反応温度の影篅}

重水の場合と同じ試料皮膜を用い，モノ重メタノール の蒸気圧 $107 \mathrm{mmHg}$ のもとで反応セルの温度をそれぞ れ55，70および80亿に保って重水素化反応を行なった。 実験結果は反応率と反応時間とを両対数プロットして Fig. 4 に示す。

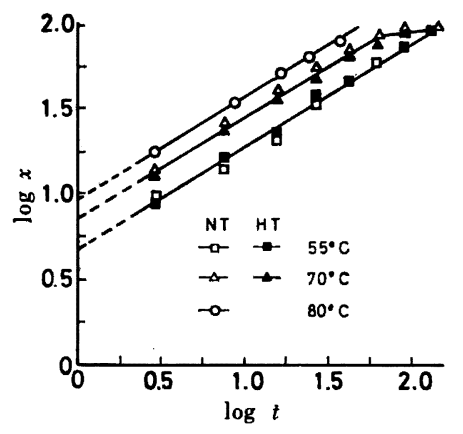

Vapor pressure of $\mathrm{CH}_{3} \mathrm{OD}: 107 \mathrm{mmHg}$

Membrane thickness: $3.0 \mu$

HT: PVA membrane heat treated at $180^{\circ} \mathrm{C}$ in $\mathrm{N}_{2}$ atmosphere

NT: none treated membrane

$\boldsymbol{x}=$ Degree of deuteration (\%)

$t=$ Reaction time (hr)

Fig. 4. Deuteration rates of PVA membranes with mono-deuterated methanol. Influence of reaction temperature and heat treatment of membranes.

これによればかなり広、筈囲にわたって直線関係が成 立し桜田ら ${ }^{6)}$ の不均一系反応速度式 $\left(x=K t^{n}\right.$, ただし $x$ は重水素化度, $t$ は反応時間, $K$ および $n$ は定数)に適合 する。重メタノール蒸気による重水素交換反応速度は重 水蒸気によるそれに比へて著しく小さく，初期反応速度 は約 $1 / 9$ にすぎないことがわかった。しかし重水による 反応の場合とは異なり, 反応温度を高めれば反応速度は 増加する。これはメタノールはPVA に対して親和性が 弱くて溶媒和しないから, 重メタノール蒸気は PVA 皮 膜にはほとんど収着されない（著者らの測定によれば70 'Cではメタノールの収着はほとんど認められなかった)。 それゆえ重水蒸気の場合のように収着量に関係する相対 圧力への重水素化反応速度の依存性はほとんどなく，む しろ，昇温による PVA 分子のミクロブラウン運動の増
大と, 重メタノール分子の熱運動の増大に基つくく PVA と重メタノールとの接触ひん度の増加による影響が大き いために反応速度が上昇するのであろう。

\section{2 .2 皮膜の厚さの影辨}

さきに述べたように，重水との交換反応においては反 応初期を除いて, 膜厚変化のせまい範囲ではあるが, 重 水素化反応速度は皮膜の厚さに無関係であることを知 り, 非晶領域と結晶領域との反応速度の違いによるもの と推論した。

重メタノールの場合にも厚さの異なる 2 種の熱処理皮 膜について重メタノール蒸気圧 $107 \mathrm{mmHg}$, 反応温度 70 Cで実験した。その結果を Fig. 5 に示す。

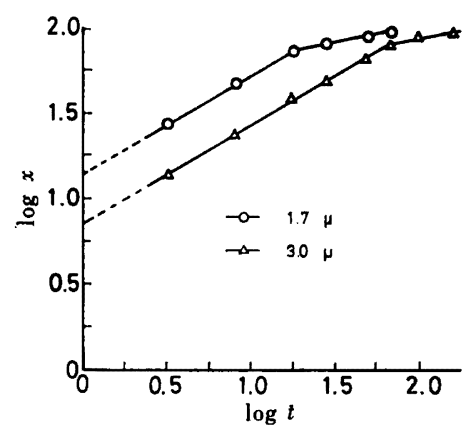

Vapor pressure of $\mathrm{CH}_{3} \mathrm{OD}: 107 \mathrm{mmHg}$

Reaction temperature: $70^{\circ} \mathrm{C}$

$x=$ Degree of deuteration (\%)

$t=$ Reaction time (hr)

Fig. 5. Deuteration rates of PVA membranes with mono-deuterated methanol. Influence of membrane thickness.

これによれば，反応速度は明らかに膜厚の影響をうけ る。いまこの直線の切片を見かけの反応速度定数 $(k)$ と 考え, それと膜厚 $(l)$ との積, 膜厚に比例すると思われ る $2910 \mathrm{~cm}^{-1}$ のレ $(\mathrm{CH})$ による吸光度 $\left(D_{\mathrm{CH}}\right)$ およびそ れと $k$ との積をみると Table 2 のようになる。

すなわち $k \times l$ および $k \times D_{\mathrm{CH}}$ の值は膜厚に無関係に 一致している。このことから反応速度が膜厚に反比例し

Table 2. Deuteration rates of PVA membranes with mono-deuterated methanol. Influence of membrane thickness.

\begin{tabular}{c|c|c|c|c}
\hline $\begin{array}{c}\text { Membrane } \\
\text { thickness }\end{array}$ & $\begin{array}{c}\text { Absorb- } \\
\text { ancy at } \\
(l) \times 10^{8} \mathrm{~mm} \\
\left(D_{\mathrm{CH}}\right)\end{array}$ & $\begin{array}{c}\text { Apparent reaction } \\
\text { rate coefficient } \\
(k)\end{array}$ & $\begin{array}{c}k \times l \\
\times 10^{3} \\
(\mathrm{~mm})\end{array}$ & $k \times D_{\mathrm{CH}}$ \\
\hline 1.7 & 0.138 & 14.5 & 24.7 & 2.0 \\
3.0 & 0.248 & 8.1 & 24.3 & 2.0 \\
\hline
\end{tabular}

Reaction temperature: $70^{\circ} \mathrm{C}$,

Vapor pressure of $\mathrm{CH}_{8} \mathrm{OD}: 107 \mathrm{mmHg}$ 
ていることがわかるが，これは重メタノール蒸気との反 応に際しては，重水蒸気の場合とは異なり，膜の表面か ら内部に向かって層状に重水素化が進行してゅくためと 考えられる。

\subsection{3 結晶化度の影艟}

重水蒸気との水素交換の場合は皮膜の結晶化度が反応 速度に影響していることは Fig. 2 抢よび Fig. 3 によっ て明らかであり,この現象は重水が非晶領域を通って皮 膜内部にまで拡散して付近の非晶性 $\mathrm{OH}$ 基を重水素化 することはきわめてすみやかであるが, 結晶領域内一拡 散して反応することはきわめて遅いことによると説明さ れた。

重メタノール蒸気による反応は Fig. 4 に示すとおり PVA の結晶化度の大小にかかわらずほぼ同し速度で重 水素化が行なわれることがわかった。これは重水の場合 のように重メタノール分子の PVA 分子煔集組織内への 拡散のみでは説明できない現象である。

PVA 固体はその数多い $\mathrm{OH}$ 基のために，結晶領域は もちろんのこと，非晶領域においてさえも分子間あるい は分子内に大量の $\mathrm{O}-\mathrm{H} \cdots \mathrm{O}$ 型の水素結合が存在する ことが想像され，野原》はNMRによってその存在を証 明しており,さらに $70^{\circ} \mathrm{C}$ ようなガラス転移点以上の温 度にあっても分子内水素結合が残存することを示してい る。

このような構造の非晶領域であるが，重水の場合は非 晶領域の水素結合を切断しながら PVA 皮膜を膨潤可塑 化し水分子の移動を容易にするのに対して, 重メタノー ルは PVA に対する親和性が少なく，水素結合を切る力 も弱いので，皮膜の内部にすばやく拡散して反応するこ とは容易でない。まして分子間凝集力の大きい結晶領城 内への拡散, 反応はそれ以上に困難であろう。

それにもかかわらずこの実験結果の示すように，非晶 領域はもちろん, 結晶領域内までも水素交換反応が及ぶ ためには，プロトン移動のような反応機構を考える必要 がある。

\subsection{4メタノールによる再水素化反応}

重メタノールによって重水素化した PVA 皮膜を, 同 し実験条件 (メタノール蒸気压 : $107 \mathrm{mmHg}$, 反応温度： 70 C）で普通のメタノールの蒸気に接触させて再水素化 する実験を行なった。その結果を Fig. 6 に示したが両 直線は完全に一致している。

このことは水素交換反応に同位元素効果がなく，また その赤外線吸収スペクトルに Beer の法則がよく適合す ることを示している。また重水あるいは重メタノールで 重水素化した試料を用いて他の試薬との間の活性水素の 交換反応を検討することができることをも示している。

\section{3 他のアルコールによる交換反応}

3.2.3 において PVA の結晶領域および非晶領域では

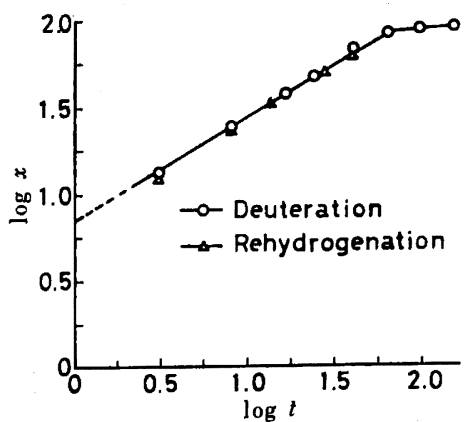

Membrane thickness: $3.0 \mu$

Vapor pressure of methanol: $107 \mathrm{mmHg}$

Reaction temperature: $70^{\circ} \mathrm{C}$

$x=$ Degree of reaction (\%)

$t=$ Reaction time $(\mathrm{hr})$

Fig. 6. Deuteration and rehydrogenation rates of PVA membrane with mono-deuterated and ordinary methanol vapor respectively.

水酸基の振動によるプロトンの送り込みと，それに基づ く水素同位体の交換反応が起こることを考えたが，これ をさらに確かめるために，メタノール上りさらに分子直 径の大きいエタノールおよび $n$-プロパノールについて, それぞれの飽和蒸気圧下で PVA 皮膜との水素交換反応 を試みた。すなわち 3.2.4の結果に基うきあらかじめ重 水によって完全に $\mathrm{OH}$ を重水素化した PVA 皮膜に $70^{\circ} \mathrm{C}$ の飽和蒸気を接触させて OD を再水素化した。その結 果をFig. 7 に示す。

これによれば反応率と反応時間との関係はほとんど全 域にわたって両対数に関して直線関係になることが認め られた。

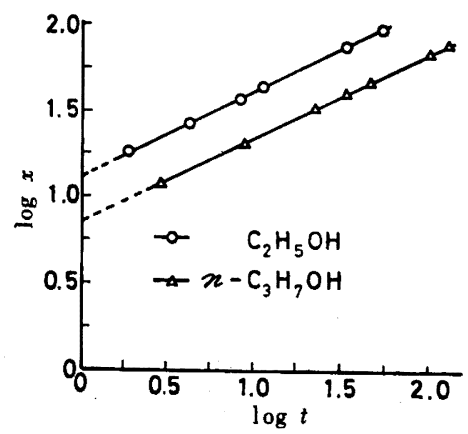

Membrane thickness: $3.0 \mu$

Reaction temperature: $70^{\circ} \mathrm{C}$

$x=$ Degree of rehydrogenation (\%)

$t=$ Reaction time (hr)

Fig. 7. Rehydrogenation rates of deuterated PVA membranes with ethanol and $n$-propanol in these saturated vapors. 
Table 3. Rehydrogenation rates of deuterated PVA membranes with ethanol and $n$-propanol.

\begin{tabular}{l|c|c|c}
\hline \multicolumn{1}{c|}{ Alcohol } & $\begin{array}{c}\text { Vapor pressure } \\
\text { at } 70^{\circ} \mathbf{C}(p) \mathbf{c m}\end{array}$ & $\begin{array}{c}\text { Apparent reaction } \\
\text { rate coeff. }\left(k^{\prime}\right)\end{array}$ & $\frac{k^{\prime}}{p}$ \\
\hline Ethanol & 56 & 12.5 & 0.22 \\
$n$-Propanol & 26 & 6.0 & 0.23 \\
\hline
\end{tabular}

Reaction temperature: $70^{\circ} \mathrm{C}$

Vapor pressure: Saturation pressure at $70^{\circ} \mathrm{C}$ respectively

いま反応速度線の切片を試料の厚さで補正した值 $\left(k^{\prime}\right)$ と蒸気圧 $(p)$ との比 $\left(k^{\prime} \mid p\right)$ をみると, Table 3 にみられ るように異なるアルコールについてほとんど一致してい る。これは再水素化反応速度は異なるアルコールを用い ても，その蒸気圧すなわち皮膜の単位面檟あたりのアル コール分子の数に比例すると考えてよいことを示してい る。いいかえれば PVA の水素交換反応速度に対して 反応試薬の分子直径は直接的には関係なく, 試薬分子の PVA 分子間への拡散も影翠しないことを意味する。し たがって結晶領域および非晶領域におけるプロトン移動 機構の存在を考えうる。

従来水, 水 ${ }^{8)}$ あるいは無機水酸化物 ${ }^{92}$ などについてブ ロトン移動の機構が考えられているが，それを PVAに .かてはめれば Fig. 8 の模式図のようになるだろう。

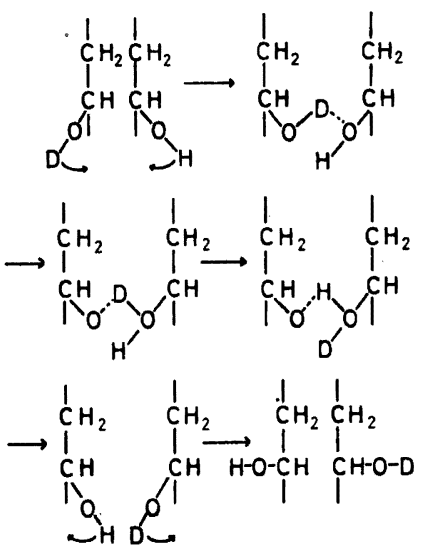

Fig. 8. Proton transfer model in PVA.

Bunn $^{10)}$ の PVA 結晶構造模型に従えば，2本 1 組にな った分子鎖が水酸基の位直を半周期ずつずらして向かい 合以, $2.97 \AA$ の $\mathrm{O}-\mathrm{H} \cdots \mathrm{O}$ 型の水素結合をつくってお り,さらに各組が $2.69 \AA$ の水素結合によって連結してa 軸に垂直な層をつくっているから，前述の機構がくり返 されれば結晶の中へ重水素化が進行してゆくことができ る.また非晶領域は結晶領域のように規則性が強くない にしても水素結合の網がはりめぐらされた状態にあり， またミクロブラウン運動がより自由であるとすれば，や
はりこのような形のプロトン送り込みの可能性を考える ことができる。

このように考えてみれば, 重メタノールとの反応にお いてみられた反応温度の影響，膜厚の影響などが重水の 場合と著しく異なる現象もプロトン移動機構によって説 明すれば容易にうなずけることである。

\section{4. 結 镸}

PVA 皮膜に重水蒸気を接触させると, PVAの $\mathrm{OH}$ 基 は部分的に $\mathrm{D}_{2} \mathrm{O}$ と水素交換反応を起こして重水素化さ れる。このことはすでに他の研究者によっても見出され たことであるが，この研究では接触がきわめて長時間に わたるときは，熱処理によって安定な結晶がつくられた ものでも，ついには $\mathrm{OH}$ 基はことごとく重水素化され ることを認めた。その理由として，これまでの他の研究 者の成果や PVA の本質的な親水性, 結晶構造の不完全 性などを考え合わせれば，重水分子が結晶格子の中まで も拡散していって活性水素交換反応を起こすことによる とみなすこともできる。

他方この研究ではさらに，モノ重メタノール，エタノ ル， $n$-プロパノールなど PVA 結晶格子内の拡散の不可 能なものによっても結晶, 非晶の区別なくPVAの全 $\mathrm{OH}$ 基の水素交換が行なわれることがわかった。その反応機 構としては PVAの OH 基相互間のプロトン移動を考え ることができる。

同様に重水による水素交換にあたっても重水分子の組 織内拡散によるばかりでなく，プロトン移動もあわせて 行なわれていると考えられる。

付 記 本研究は繊維学会昭和 44 年度年次大会 (昭和44 年 5 月 13 日, 東京) および第15回高分子研究発表会（昭 和44年 7 月 12 日, 神戸) において講演したものである。 また本研究の実施にあたりご助言を賜わった東京都立大 学工学部岡島三郎教授, 甲斐昭講師の両氏に深く感謝い たします。

\section{文献}

1) 高橋直通, 鈴木文男, 小野里健二 : 高化, 26, 352 (1969)

2) 田所宏行, 関 集三，仁田 勇 : 日化, 78, 168 (1957)

3) 石川欣造, 宮坂啓象, 山本清昭 : 高化, 25, 50 (1968)

4) E. C. Evars, A. G. Knox: J. Am. Chem. Soc., 73, 1739 (1951)

5) S. Okajima, A. Kai: J. Polymer Soc., A-1, 6, 2801 (1968)

6) 桜田一郎 : 工化, 36, 783 (昭8)

7) 野原繁三: 高化, 15, 105 (1958)

8) たとえば W.J. Moore: Physical Chemistry 3rd ed., (1962), 丸善

9) K. J. Gallagher, D. N. Phillips: Trans. Faraday Soc., 64, 785 (1968)

10) C. W. Bunn: Nature, 161, 929 (1948) 


\title{
English Summaries of the Papers 掲载論文英文要旨
}

\section{Structure and Polymerizability of $\alpha, \beta$-Unsaturated Ethers}

\author{
by Tadashi Okuyama* and Takayuki Fueno*
}

[Kobunshi Kagaku, Vol. 28, No. 313, pp. 369-380 (May, 1971)]

Cationic polymerizability of $\alpha, \beta$-unsaturated ethers are discussed in particular attention to their geometrical structure and kinetic behavior. The ethers investigated include alkenyl alkyl, phenyl vinyl, styryl ethyl and $\beta$-chlorovinyl ethyl ethers. 1,2-Dialkoxyethylenes and benzofuran have also been studied. Comparisons of their general behavior in polymerization with that in the acid-catalyzed hydrolysis, which involves the rate-determining protonation, have manifested an important discrimination in the nature of the transition states between the two reactions. It is generally concluded for the cationic polymerization that rotation about the C-C bond of the polymer end unit is restricted in the transition state and that its structure may be represented by a $\pi$-complex-type or cyclic model such as the<smiles>[R]OC1(C)[C@@]2(C)C[C@]12C</smiles>
following:

KEY WORDS Vinyl Ethers/Copolymerization/Substituent Effects/ $\pi$-Complex-type _Transition State/

* Department of Chemistry, Faculty of Engineering Science, Osaka University (Machikaneyama, Toyonaka, Osaka)

\section{Exchange Reaction of Active Hydrogen Atoms between PVA and Water or Lower Aliphatic Alcohol} by Naomichi Takahashi*, Fumio Suzuki*, and Kenji Onozato*

[Kobunshi Kagaku, Vol. 28, No. 313, pp. 380-385 (May, 1971)]

For the study of deuteration mechanism of PVA, the exchange reaction of active hydrogen atoms between PVA membranes (heat treated and non-treated) and the vapors of water and aliphatic alcohols (methanol, ethanol and $n$-propanol) were investigated.

The degree of exchange reaction was measured by IR-spectroscopic method.

At first, the deuteration rate of PVA with heavy water vapor was studied, and the following results were obtained:

(1) Except the early stage of reaction, the reaction rates had no relation to the membrane thickness of PVA.

(2) The apparent rates of deuteration decreased at higher reaction temperature under a definite vapor pressure.

(3) The degree of deuteration of PVA amounted to $100 \%$ at equilibrium irrespective of heat treatment.

Next, the exchange reactions were studied by deuteration and rehydrogenation with lower aliphatic alcohols which seemed unable to diffuse into the crystalline region of PVA, and the results were as follows:

The apparent reaction rates were (1) lower in comparison with those by heavy water, (2) in inverse

* Department of Polymer Chemistry, Faculty of Engineering, Yamagata University (Yonezawa Yamagata) 
proportion to the thickness of membranes, (3) not influenced by the degree of crystallinity of PVA, (4) faster at higher reaction temperature, and (5) in proportion to the vapor pressure of alcohols. And the degree of reaction amounted to $100 \%$ at equilibrium as same as the reaction with heavy water.

From above results it was supposed that the exchange reaction of active hydrogen atoms between alcohol and PVA must proceed by "proton transfer" in crystalline region, and probably in amorphous region too.

This mechanism may be also applied partially to the exchange reaction with heavy water, especially in crystalline region.

KEY WORDS Denteration/Rehydrogenation/Polyvinyl Alcohol Proton Transfer/Accessibility/

\title{
Vinyl Polymerization
}

\section{GGLXVI $^{* 1}$. Polymerization of Vinyl Monomers in the Presence of Cellulose Acetate Fiber}

\author{
by Kanemitsu Kubushiro*, Kiichi Takemoto**, and Minoru Imoto*** \\ [Kobunshi Kagaku, Vol. 28, No.313, pp. 386-388 (May, 1971)]
}

Polymerization of vinyl monomers initiated with cellulose acetate fiber was carried out in the presence of water, carbon tetrachloride or $n$-hexane, and the relationship between the polymerizability and the condition of polymerization system was examined. In the case of styrene, small amount of polymer was obtained. With the exception of styrene, only acrylates and methacrylates showed the polymerizability. Some of monomers showed either higher or lower polymerizability by the addition of water.

The acceleration of polymerization by carbon tetrachloride was more or less observed in each monomer. The acceleration effect of $n$-hexane was only observed in the case of methyl methacrylate. Copolymerization of methyl methacrylate and styrene was carried out in the presence or absence of carbon tetrachloride, and the deviation of the values of monomer reactivity ratio from reported ones by Mayo et al. was discussed.

KEY WORDS Polymerization/Vinyl Monomer/Cellulose Acetate/Carbon Tetrachloride/

* Central Research Laboratory, Mitsubishi Petrochem. Co., Ltd. (Ami-machi, Inashiki-gun, Ibaragi)

** Faculty of Engineering, Osaka University (Yamada-gami, Suita, Osaka)

*** Faculty of Engineering, Osaka City University (Sugimoto-cho, Sumiyoshi-ku, Osaka)

*1 265th of series: M. Imoto, A. Tanaka, K. Ueno, K. Takemoto, Angew. Makromoleculare Chem., in press.

\section{The Polymerization Mechanism of Acrylamide Initiated by Ceric Ion}

\author{
by Hiroshi Narita* and Seishi Machida*
}

[Kobunshi Kagaku, Vol. 28, No. 313, pp. 389-395 (May, 1971)]

\footnotetext{
* Chemical Laboratory of Textile Fibers, Kyoto University of Industrial Arts and Textile Fibers (Matsugasaki, Sakyo-ku, Kyoto)
} 